\title{
Simulation of alternative implementation scenarios for the Metro system in Seville
}

\author{
J. Muñuzuri, J. N. Ibáñez, P. Cortés \& J. Guadix \\ School of Engineering, University of Seville, Spain
}

\begin{abstract}
The building of the Metro system in Seville is clearly defined in terms of the network layout, but not so much in terms of the final configuration of the lines. For some of them, due to cost criteria, on-surface tracks are being considered, which would clearly have an effect both on the public transport system and on the passenger car traffic around it, due to the reduction of road space. A macroscopic simulation approach, using the commercial package EMME/2, is used to assess the effects of such implementation, and thus estimate the feasibility of the different Metro Lines. The required O-D matrix modifications to represent the scenarios considered and the upgrading of the city network are described in the paper, as well as the conclusions drawn from the simulations. Keywords: Metro, macroscopic simulation, $O-D$ matrices.
\end{abstract}

\section{The Metro system in Seville}

\subsection{Configuration of the lines}

The planned Metro system in Seville [1] is composed of four lines, as depicted in Figure 1. Lines 1 and 2 have an East-West trajectory, while Line 3 runs from North to South and Line 4 is circular. Line 1 is already under construction, and is expected to start operating in 2008, with Lines 3, 2 and 4 to follow, still without expected dates.

Line 1 runs from Ciudad Expo, on the South-West of the city, to Olivar de Quinto, on the South-East. This line will have an effect on the number of passengers using other transport modes, but not on the configuration of the road network, since most of its route inside the urban area runs underground, and does not affect the existing road system outside of it. 
However, while the other three lines are totally defined in terms of their routes, in the case of Lines 3 and 4 there remains the issue of whether some of their links will go underground or on the surface. And in the case of these lines, it would have an effect on the surrounding road network, as well as on the construction cost of the infrastructure. Even though this work focuses only on the effects of the different implementation scenarios on the traffic system, it is evident that significant reductions in the building cost can be achieved by reducing the number of links that run underground.

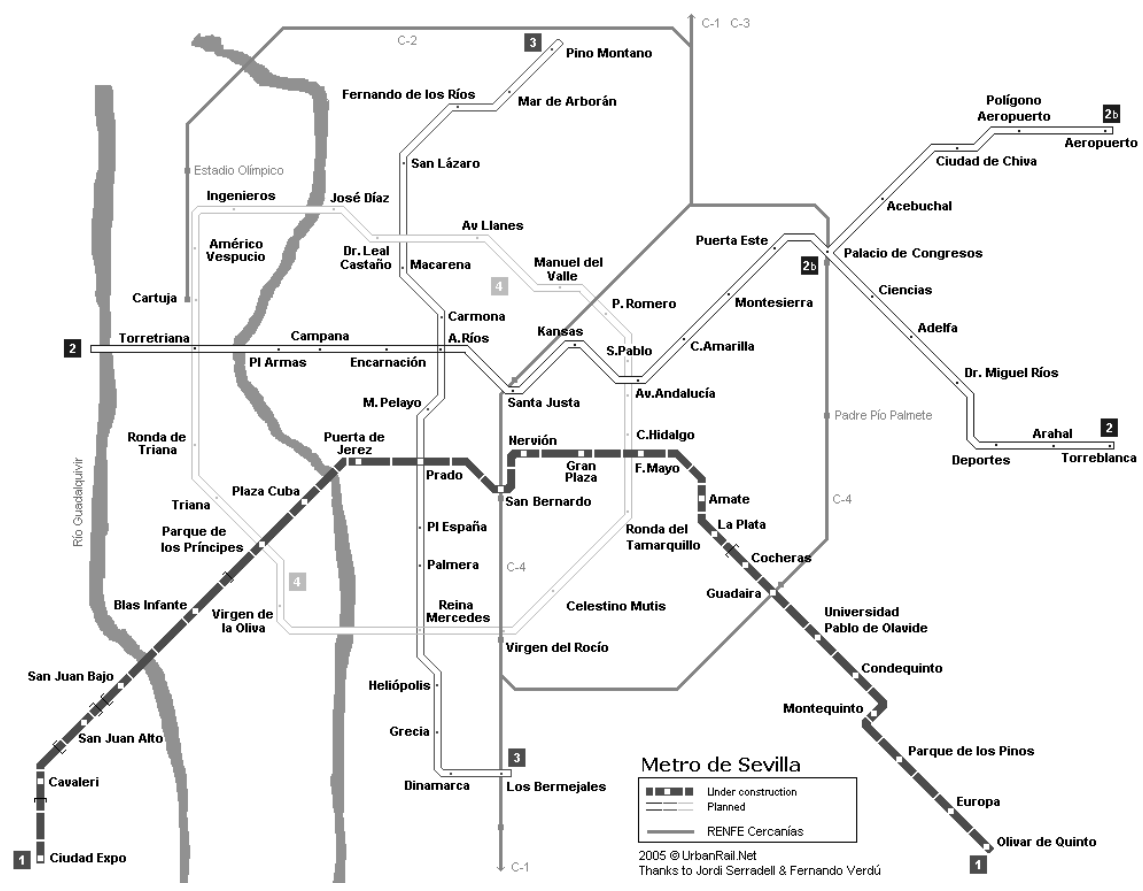

Figure 1: Planned layout of the Metro system in Seville.

Table 1: $\quad$ Alternative scenarios for the Metro system in Seville.

\begin{tabular}{|c|l|l|}
\hline LINE & \multicolumn{1}{c|}{ DESCRIPTION } \\
\hline Line 1 & Underground from Blas Infante to Guadaira \\
\hline Line 2 & Underground from Torretriana to Santa Justa \\
\hline \multirow{2}{*}{ Line 3 } & Alternative 3.1 & \multicolumn{2}{|c|}{ Underground from Prado to Macarena } \\
\cline { 2 - 3 } & Alternative 3.2 & Completely on surface \\
\hline \multirow{2}{*}{ Line 4 } & Alternative 4.1 & $\begin{array}{l}\text { Underground from Ronda de Triana to Virgen } \\
\text { del Rocío }\end{array}$ \\
\cline { 2 - 3 } & Alternative 4.2 & $\begin{array}{l}\text { Underground from Parque de los Príncipes to } \\
\text { Virgen del Rocío }\end{array}$ \\
\hline
\end{tabular}




\subsection{Alternative scenarios considered}

Table 1 shows the different alternatives considered for the Metro system in Seville. As stated before, the design of Lines 1 and 2 is fixed, and the question remains about the effect of the two considered alternatives for Lines 3 and 4 on the surrounding traffic.

Table 2: $\quad$ General dimensions of Line 2.

\begin{tabular}{|l|l|}
\hline \multicolumn{1}{|c|}{ Concept } & \multicolumn{1}{c|}{ Value } \\
\hline Commercial speed & $28^{\prime} 51 \mathrm{~km} / \mathrm{h}$ \\
\hline Total travel time & $30^{\prime} 54 \mathrm{~min}$ \\
\hline Number of trains in operation & 8 units per direction (16 units in total) \\
\hline Number of trains in reserve & 2 units \\
\hline Total number of trains & 18 units \\
\hline
\end{tabular}

Table 3: $\quad$ Base-year demand for Line 2.

\begin{tabular}{|c|c|c|c|c|c|}
\hline Origin Station (1) & Destination Station (2) & 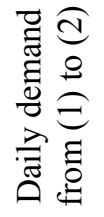 & 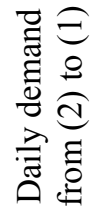 & 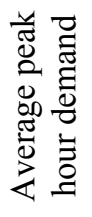 & 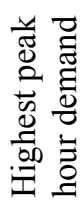 \\
\hline $\begin{array}{l}\text { 18. Príncipe de } \\
\text { Asturias }\end{array}$ & 17. Arahal & 87 & 246 & 13 & 21 \\
\hline 17. Arahal & 16. Deporte & 87 & 249 & 14 & 22 \\
\hline 16. Deporte & 15. Miguel Ríos & 478 & 372 & 26 & 41 \\
\hline 15. Miguel Ríos & 14. Adelfas & 1929 & 1793 & 102 & 162 \\
\hline 14. Adelfas & 13. Ciencias & 2391 & 2374 & 126 & 201 \\
\hline 13. Ciencias & 12. Palacio exposición & 4438 & 4349 & 234 & 374 \\
\hline 12. Palacio expo. & 11. Puerta Este & 5174 & 5610 & 295 & 472 \\
\hline 11. Puerta Este & 10. Moraleja & 5793 & 5960 & 314 & 502 \\
\hline 10. Moraleja & 9. Montesierra & 6813 & 6980 & 367 & 588 \\
\hline 9. Montesierra & 8. Utrera Molina & 6991 & 7283 & 383 & 613 \\
\hline 8. Utrera Molina & 7. San Pablo & 7578 & 8691 & 457 & 732 \\
\hline 7. San Pablo & 6. Kansas City & 10952 & 10144 & 576 & 922 \\
\hline 6. Kansas City & 5. Santa Justa & 11845 & 11010 & 623 & 997 \\
\hline 5. Santa Justa & 4. Amador de los Ríos & 12225 & 11656 & 643 & 1029 \\
\hline $\begin{array}{l}\text { 4. Amador de los } \\
\text { Ríos }\end{array}$ & 3. Plaza Encarnación & 11608 & 11655 & 613 & 982 \\
\hline 3. Encarnación & 2.Plaza Armas & 8967 & 9177 & 483 & 773 \\
\hline 2.Plaza Armas & 1.Expo & 4949 & 4223 & 260 & 417 \\
\hline
\end{tabular}




\section{Information about the lines}

Apart from the routes followed by the different Lines, some further information about them was available in [1] and [2], which will be summarised in this section only for Line 2, due to the space limitations. This information has been issued by the Seville Metro Society, which is responsible for the execution of the building works.

In general, a maximum speed of $50 \mathrm{~km} / \mathrm{h}$ has been estimated for the onsurface links, and $70 \mathrm{~km} / \mathrm{h}$ for the subterranean ones, with a maximum acceleration rate of $1.2 \mathrm{~m} / \mathrm{s}^{2}$. Apart from this, the following Tables display the rest of data available for Line 2 . In Table 3, the highest peak hour demand corresponds to the direction of the Line (West to East or East to West) with the highest demand in each link during the peak hour.

Table 4: $\quad$ Effects caused by Line 2 on the capacity of road links.

\begin{tabular}{|l|c|c|c|c|}
\hline \multicolumn{1}{|c|}{ Link } & $\begin{array}{c}\text { Current } \\
\text { capacity }\end{array}$ & $\begin{array}{c}\text { Hourly } \\
\text { flow }\end{array}$ & $\begin{array}{c}\text { Reduced } \\
\text { capacity }\end{array}$ & $\begin{array}{c}\text { Capacity } \\
\text { reduction }\end{array}$ \\
\hline C/ Gonzalo Bilbao & 1027 & 483 & 1027 & $0 \%$ \\
\hline C/ Juan Antonio Cavestany & 2054 & 1450 & 2054 & $0 \%$ \\
\hline Av. Kansas City & 4320 & 3212 & 4320 & $0 \%$ \\
\hline C/ Éfeso C/ A.D.A. & 3520 & 2850 & 2347 & $33 \%$ \\
\hline $\begin{array}{l}\text { C/ Éfeso C/ A.D.A. con Línea } \\
4\end{array}$ & 3520 & 2850 & 1173 & $67 \%$ \\
\hline Av. Montesierra & 4601 & 2725 & 2301 & $50 \%$ \\
\hline Av. Luis Uruñuela & 5199 & 3643 & 3466 & $33 \%$ \\
\hline Av. de las Ciencias & 7824 & 1602 & 5868 & $25 \%$ \\
\hline C/ De la Aeronáutica & 7824 & 2846 & 5868 & $25 \%$ \\
\hline Ramal Aeropuerto. C/ Secoya & 3010 & 1478 & 1505 & $50 \%$ \\
\hline
\end{tabular}

Table 5: $\quad$ Effects caused by Line 2 on road turns.

\begin{tabular}{|c|c|c|}
\hline Link & Node & Eliminated turns \\
\hline $\begin{array}{c}\text { Av. Kansas } \\
\text { City }\end{array}$ & C/ Éfeso & $\begin{array}{c}\text { Giro izquierda Éfeso / Soleá. Giro } \\
\text { izquierda D. Laffón / Éfeso. }\end{array}$ \\
\hline C/ Éfeso & $\begin{array}{c}\text { C/ Doctor Laffón / } \\
\text { Av. de la Soleá }\end{array}$ & $\begin{array}{c}\text { Giro izquierda Éfeso / Soleá. Cruce D. } \\
\text { Laffón / Soleá. Cruce Soleá / D. Laffón. }\end{array}$ \\
\hline $\begin{array}{c}\text { Av. de } \\
\text { Montesierra }\end{array}$ & C/ Rafael Beca & Giro izquierda Montesierra / Rafael Beca. \\
\hline $\begin{array}{c}\text { Av. Luis } \\
\text { Uruñuela }\end{array}$ & $\begin{array}{c}\text { C/ Jesús García } \\
\text { Díaz }\end{array}$ & $\begin{array}{c}\text { Cruce Urb. Puerta Este / Jesús García } \\
\text { Díaz. Giro izquierda Urb. Puerta Este / } \\
\text { Luis Uruñuela. }\end{array}$ \\
\hline
\end{tabular}




\section{Setting up of the simulations}

\subsection{O-D matrix upgrading to reflect population growth}

The effect of the implementation of the Metro system on the Seville transport scenario was analysed with macroscopic simulation using the EMME/ $2{ }^{\circledR}$ tool [3]. Already available was the city road network with the bus line information, as well as the O-D matrices for passenger cars and public transport during the morning peak hour. These matrices correspond to 1993, and therefore two different upgrading processes had to be carried out:

- A 15-year upgrading, in order to estimate matrices for 2008, when Line 1 is to start operating.

- A 30-year upgrading to 2023, when the entire Metro network is expected to be concluded.

The process carried out consisted on the estimation of the population in the different districts of the city and the nearby towns for 2008 and 2023, by means of linear extrapolation from the available data for 1991, 1996 and 2001. Then a simple restricted growth model [4] was applied, multiplying each row of the O-D matrices by the corresponding coefficient:

$\frac{\text { Population of the zone in } 2008}{\text { Population of the zone in } 1993}$ or $\quad \frac{\text { Population of the zone in } 2023}{\text { Population of the zone in } 1993}$

Thus, the number of trips generated in each zone of the metropolitan area, both for passenger cars and for public transport (including buses and Metro), will increase proportionally depending on the increase of population in the zone. As opposed to this approach, in the double restricted growth model, both the rate growth of transport demand in origins (rows) and destinations (columns) are known, which is not the case here.

\subsection{Increase in the use of public transport due to the existence of the Metro system}

The main problem to be solved by the building of the Metro system in Seville is the unstoppable growth of passenger car traffic, which is currently almost $80 \%$ of the total number of trips, with public transport accounting for the remaining $20 \%$ and decreasing every year.

The estimated demand for the use of the Metro system, shown above for Line 2 but available for all the Lines, can be used to estimate the shift of transport demand towards public transport after the opening of the different Lines.

In order to do so, the different transport corridors were analysed [5], and the EMME/2 zones to be used for the simulation were divided into "Metro" zones 
(those adjacent to Metro Lines) and "Non-Metro" zones. Different scenarios were then considered:

- $\quad$ For the 2008 estimation, after the opening of Line 1), the existing modal share $(79.21 \%$ for passenger car traffic and $20.79 \%$ for public transport) was considered, as well as the demand shift expected by the Seville local authorities $(70 \%$ for passenger car transport in the Metro zones and $30 \%$ for public transport).

- For the 2023 estimation, after the Metro network is completely finished, three different scenarios were considered for modal share in the Metro zones: $75 \%-25 \%, 70 \%-30 \%$ and $65 \%-35 \%$.

The resulting expected demands are shown in the following Tables. It can be seen that the finalisation of the Metro network in 2023 results in a large increase in the number of Metro zones with respect to 2008, and subsequently of the number of trips between them.

Table 6: 2008 scenario maintaining the current percentages.

\begin{tabular}{|c|c|c|c|c|}
\hline $\begin{array}{c}\text { Trip } \\
\text { type }\end{array}$ & $\begin{array}{c}\text { Total } \\
\text { number } \\
\text { of trips }\end{array}$ & $\begin{array}{c}\text { Percentage of } \\
\text { the total } \\
\text { number of trips }\end{array}$ & $\begin{array}{c}\text { Number of trips } \\
\text { between Metro } \\
\text { zones }\end{array}$ & $\begin{array}{c}\text { Percentage of the } \\
\text { total number of trips } \\
\text { in Metro zones }\end{array}$ \\
\hline Car & 137,762 & $80.87 \%$ & 19,883 & $79.21 \%$ \\
\hline Public & 32,593 & $19.13 \%$ & 5,218 & $20.79 \%$ \\
\hline Total & 170,355 & $100.00 \%$ & 25,101 & $100.00 \%$ \\
\hline
\end{tabular}

Table 7: $\quad 2008$ scenario with a 70\%-30\% modal share in Metro zones.

\begin{tabular}{|c|c|c|c|}
\hline Trip type & $\begin{array}{c}\text { Percentage of the total } \\
\text { number of trips } \\
\text { between Metro zones }\end{array}$ & $\begin{array}{c}\text { Number of trips } \\
\text { between Metro } \\
\text { zones }\end{array}$ & $\begin{array}{c}\text { Reduction of } \\
\text { passenger car use } \\
\text { between Metro zones }\end{array}$ \\
\hline Car & $70 \%$ & 17,571 & $11.63 \%$ \\
\hline Public & $30 \%$ & 7,530 & \\
\hline Total & $100 \%$ & 25,101 & \\
\hline
\end{tabular}

Table 8: 2023 scenario maintaining the current percentages.

\begin{tabular}{|c|c|c|c|c|}
\hline $\begin{array}{c}\text { Trip } \\
\text { type }\end{array}$ & $\begin{array}{c}\text { Total } \\
\text { number } \\
\text { of trips }\end{array}$ & $\begin{array}{c}\text { Percentage of } \\
\text { the total } \\
\text { number of trips }\end{array}$ & $\begin{array}{c}\text { Number of trips } \\
\text { between Metro } \\
\text { zones }\end{array}$ & $\begin{array}{c}\text { Percentage of the } \\
\text { total number of trips } \\
\text { in Metro zones }\end{array}$ \\
\hline Car & 161,080 & $81.29 \%$ & 132,227 & $80.20 \%$ \\
\hline Public & 37,076 & $18.71 \%$ & 32,635 & $19.80 \%$ \\
\hline Total & 198,155 & $100.00 \%$ & 164,862 & $100.00 \%$ \\
\hline
\end{tabular}


Table 9: $\quad 2023$ scenario with a $75 \%-25 \%$ modal share in Metro zones.

\begin{tabular}{|c|c|c|c|}
\hline Trip type & $\begin{array}{c}\text { Percentage of the total } \\
\text { number of trips } \\
\text { between Metro zones }\end{array}$ & $\begin{array}{c}\text { Number of trips } \\
\text { between Metro } \\
\text { zones }\end{array}$ & $\begin{array}{c}\text { Reduction of } \\
\text { passenger car use } \\
\text { between Metro zones }\end{array}$ \\
\hline Car & $75 \%$ & 123,647 & $6.49 \%$ \\
\hline Public & $25 \%$ & 41,216 & \\
\hline Total & $100 \%$ & 164,862 & \\
\hline
\end{tabular}

Table 10: 2023 scenario with a 70\%-30\% modal share in Metro zones.

\begin{tabular}{|c|c|c|c|}
\hline Trip type & $\begin{array}{c}\text { Percentage of the total } \\
\text { number of trips } \\
\text { between Metro zones }\end{array}$ & $\begin{array}{c}\text { Number of trips } \\
\text { between Metro } \\
\text { zones }\end{array}$ & $\begin{array}{c}\text { Reduction of } \\
\text { passenger car use } \\
\text { between Metro zones }\end{array}$ \\
\hline Car & $70 \%$ & 115,403 & $12.72 \%$ \\
\hline Public & $30 \%$ & 49,459 & \\
\hline Total & $100 \%$ & 164,862 & \\
\hline
\end{tabular}

Table 11: 2023 scenario with a 65\%-35\% modal share in Metro zones.

\begin{tabular}{|c|c|c|c|}
\hline Trip type & $\begin{array}{c}\text { Percentage of the total } \\
\text { number of trips } \\
\text { between Metro zones }\end{array}$ & $\begin{array}{c}\text { Number of trips } \\
\text { between Metro } \\
\text { zones }\end{array}$ & $\begin{array}{c}\text { Reduction of } \\
\text { passenger car use } \\
\text { between Metro zones }\end{array}$ \\
\hline Car & $65 \%$ & 107,160 & $18.96 \%$ \\
\hline Public & $35 \%$ & 57,702 & \\
\hline Total & $100 \%$ & 164,862 & \\
\hline
\end{tabular}

\subsection{Changes in O-D matrices due to the different modal shares}

The upgraded O-D matrices for 2008 and 2023 were modified as follows in order to account for the different modal share scenarios described in the previous section:

- First, private car traffic between Metro zones is reduced in the corresponding percentage. For example, in the case of the scenario described in Table 7, the corresponding O-D pairs of the private car matrix were reduced by $11.63 \%$.

- Second, the number of public transport trips between the same Metro zones is increased in the same percentage. Thus, the total number of trips generated in the zone remains constant.

\subsection{Network upgrading}

Finally, the Metro Line 1 was introduced in the 2008 EMME/2 network, and the other three Lines were also introduced in the 2023 network. This also included 
the modification of turns (when a two-way street becomes one-way) and road capacities, as shown in Tables 4 and 5.

It must be noted that the existing bus lines were maintained as they are, with the same routes and speed, given that no modifications have been suggested by the local authorities yet. It is nevertheless to be expected that several bus lines will be eliminated or modified, depending on the performance of the Metro system, and the remaining ones will have different commercial speeds due to the changes in travel times caused by the introduction of the Metro.

\section{Simulation results and conclusions}

The main results obtained from the simulations carried out in EMME/2 for the different scenarios were the vehicle flows and the travel times in the different road links. Figures 2 and 3 illustrate these results for an area close to the city centre.

The main conclusions that can be drawn from these results are not referred to Lines 1 and 2, which are completely defined, but to the other two. In the case of the scenario with Line 3 running fully on the surface, this Line does not seem to absorb enough demand, due to the reduced speed with respect to underground links.

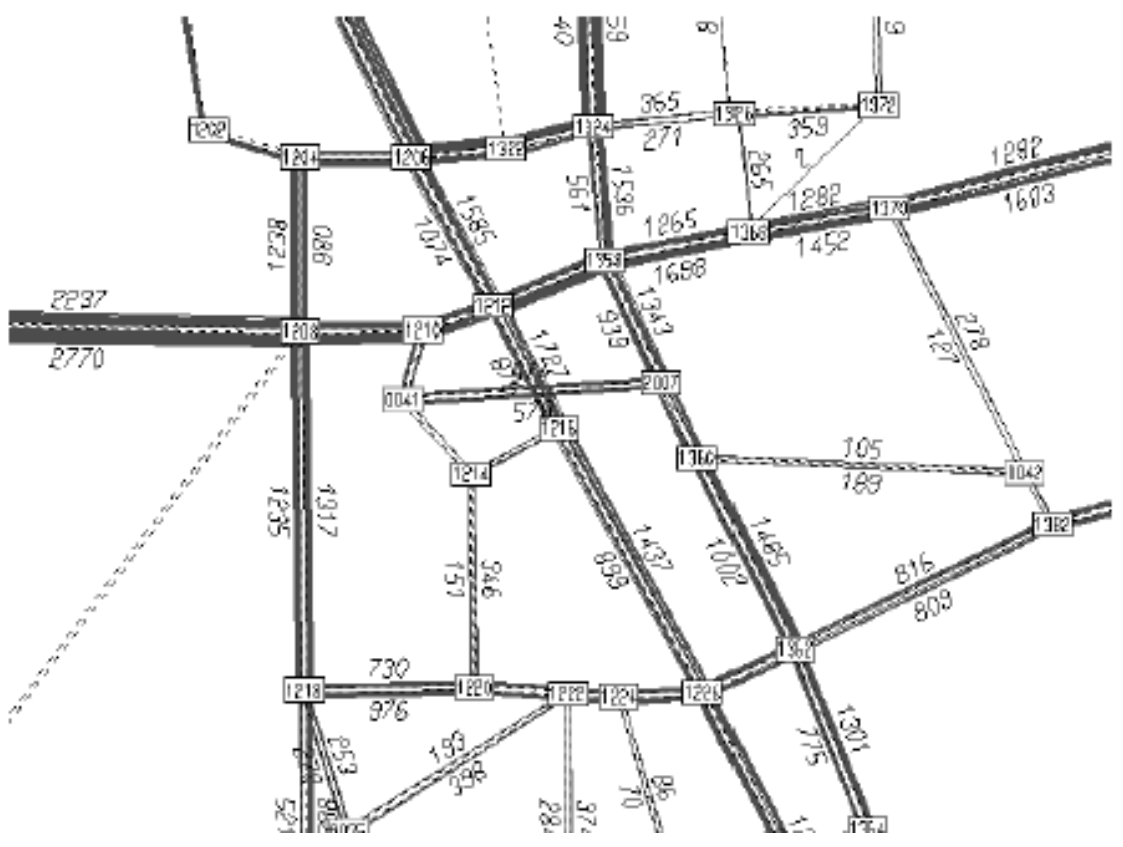

Figure 2: Vehicle flows in road links. 


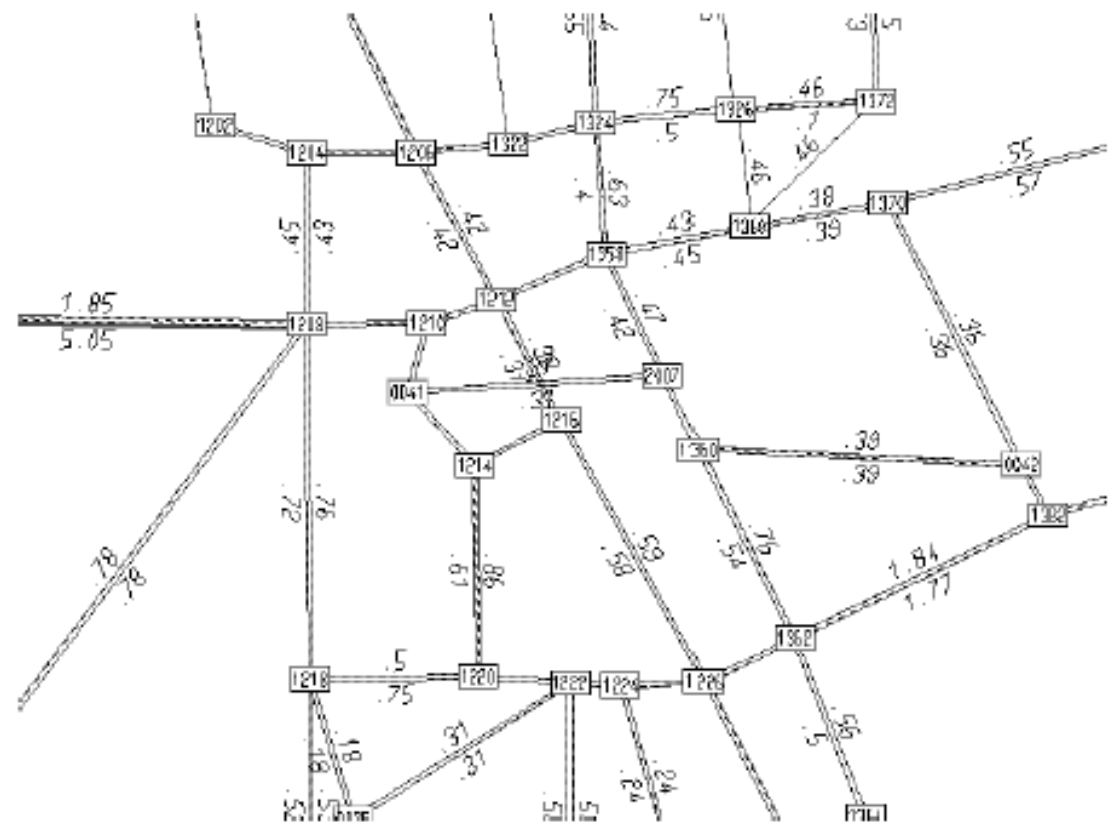

Figure 3: Travel times in road links.

Line 4, on the other hand, presents the lowest demand rates, possibly due to its long length and to the fact that it is faster to cover most Metro zones using the other three lines to cross the city centre than moving around it in a wide circle. In general, it seems that the decision to build Lines 1 and 3 first is adequate, as they absorb most of the demand expected in the Metro network.

With respect to the effects on car traffic, the increase in travel times are often significant, especially due to the crossings of high-capacity streets with the Metro Lines. Especially problematic is the crossing between lines 2 and 4 in Av. Andalucía, with great reductions needed in the capacity of the road links in an already congested area. In some cases the increase in travel times was found to be not too significant, possibly due to the reduction of the number of passenger cars in the most favourable scenarios, but the reduction of the capacity of the road links caused increases in vehicle flows in the adjacent streets, thus spreading congestion problems.

All these facts should possibly lead to reconsiderations of many of the onsurface links, in view of the mobility problems that could be generated. It is true that worsening the conditions for road transport is one of the methods for switching demand towards public transport [6], but his does not seem to be the correct approach in this case, with a large city requiring increasing mobility patterns, some of which are not easily transferred to a Metro system, like goods transport. Without taking into consideration the cost factor, it seems that the proposed Metro network with many on-surface links is not suitable for the city of Seville. 


\section{References}

[1] Metro de Sevilla, S.A. (2001), Proyecto Básico General de la Red de Metro de Sevilla y Programación de Fases. Estudio de Impacto Ambiental, Metro de Sevilla, S.A.

[2] Consejería de Obras Públicas y Transporte, (2002), Memoria del Anteproyecto de la Línea 1 Interurbana del Metro de Sevilla, Junta de Andalucía.

[3] Center for Research on Transportation of the University of Montreal, (1994), EMME/2 User's Manual, INRO Consultants Inc.

[4] Quine M.P., Robinson J. (1992) Estimation for a linear growth model, Statistics and Probability Letters, 15, 293-297.

[5] Golias, J.C. (2002) Analysis of traffic corridor impacts from the introduction of the new Athens Metro system. Journal of Transport Geography, Volume 10, Issue 2, Pages 91-97.

[6] Justo J.L. (1994), Pasado y Futuro del Metro de Sevilla, Secretariado de Publicaciones de la Universidad de Sevilla. 